\title{
Perbanyakan Anggrek Spesies Paphiopedilum glaucophyllum J.J.Smith melalui Proliferasi Tunas Adventif Secara In Vitro
}

\author{
Propagation of Paphiopedilum glaucophyllum J.J.Smith orchid through Adventitious Shoot \\ Proliferation via In Vitro
}

\author{
Tubagus Kiki Kawakibi Azmi ${ }^{1}$ dan Ni Made Armini Wiendi ${ }^{2 *}$ \\ Diterima 19 Agustus 2013/Disetujui 23 Oktober 2013
}

\begin{abstract}
This research was aimed to determine the effects of BAP and medium on adventitious shoot proliferation of Paphiopedilum glaucophyllum J.J. Smith in vitro. Plantlet of 1 year 9 months old from seed germination in vitro on modified Knudson $C$ medium was used as an explant. This research was arranged in a Factorial Design with three replications. The first factor was different concentration of BAP, consisting of 1 and $2 \mathrm{mg} \mathrm{L}^{-1}$ (All combination medium were added with 0.5 $\left.m g L^{-1} 2.4-D\right)$. The second factor was different concentration of macro and micro nutrient from $M S$ (Murashige and Skoog) and KC (Knudson C) medium, consisting of 1, 3/4, 1/2, and 1/4 concentrations of macro and micro nutrient. The result showed that plantlets failed to response to the entire adventitious shoot proliferation combination medium within 16 weeks. Concentration of medium affected to leaves and root growth. The optimum growth was achieved at 3/4 concentration of macro and micro nutrient from KC medium, combined with $2 \mathrm{mg} \mathrm{L}^{-1} B A P$ for leaves growth and $1 \mathrm{mg} L^{-1}$ $B A P$ for root growth. BAP affected callus induction. The highest percentage of callus induction was achieved at $1 \mathrm{mg} \mathrm{L}^{-1} B A P(48.61 \%)$.
\end{abstract}

Key words: BAP, KC, MS, medium, proliferation.

\begin{abstract}
ABSTRAK
Penelitian dilakukan untuk mempelajari pengaruh zat pengatur tumbuh BAP dan media MS (Murashige \& Skoog) dan KC (Knudson C) terhadap kemampuan proliferasi tunas adventif Paphiopedilum glaucophyllum J.J.Smith secara in vitro. Bahan tanaman yang digunakan adalah planlet hasil pengecambahan biji secara in vitro yang telah berumur 1 tahun 9 bulan yang diperoleh dari Pusat Konservasi Tumbuhan, Kebun Raya, Bogor. Penelitian menggunakan Rancangan Acak Lengkap (RAL) dengan dua faktor perlakuan yang disusun secara faktorial dengan tiga ulangan. Faktor pertama adalah BAP yang terdiri dari 1 dan $2 \mathrm{mg} \mathrm{L}^{-1}$, penggunaan BAP dikombinasikan dengan $0.5 \mathrm{mg} \mathrm{L}^{-1}$ 2.4-D. Faktor kedua adalah media (MS dan KC) dengan konsentrasi hara makro dan mikro masing-masing adalah $1,3 / 4,1 / 2$, dan $1 / 4$ konsentrasi. Hasil penelitian menunjukkan bahwa proliferasi tunas adventif tidak terjadi pada semua perlakuan. Konsentrasi media (MS dan KC) berpengaruh nyata terhadap pertumbuhan daun dan akar. Pertumbuhan daun dan akar optimum diperoleh pada $3 / 4$ konsentrasi hara makro dan mikro pada kedua jenis media. Pertumbuhan daun tertinggi diperoleh pada media $\mathrm{KC} \mathrm{3/4} \mathrm{konsentrasi} \mathrm{hara} \mathrm{makro} \mathrm{dan} \mathrm{mikro} \mathrm{ditambah} 2 \mathrm{mg} \mathrm{L}{ }^{-1}$. Media KC $3 / 4$ konsentrasi hara makro dan mikro ditambah $1 \mathrm{mg} \mathrm{L}^{-1}$ menghasilkan jumlah total akar tertinggi. BAP berpengaruh nyata terhadap persentase planlet berkalus. Jumlah planlet berkalus tertinggi diperoleh pada media yang mengandung $1 \mathrm{mg} \mathrm{L}^{-1} \mathrm{BAP}(48.61 \%)$.
\end{abstract}

Kata kunci: BAP, KC, MS, media, proliferasi.

\footnotetext{
${ }^{1}$ Alumni Departemen Agronomi dan Hortikultura, Fakultas Pertanian, Institut Pertanian Bogor

${ }^{2}$ Staf Pengajar Departemen Agronomi dan Hortikultura, Fakultas Pertanian-Institut Pertanian Bogor, Jl. Meranti, Kompleks IPB

Darmaga Bogor, 16680.Indonesia. Telp Fax : 0251 8629353, E-mail: nmarmini@yahoo.com (*penulis korespondensi)
} 


\section{PENDAHULUAN}

Paphiopedilum glaucophyllum J. J. Smith adalah salah satu spesies dari genus Paphiopedilum dalam famili Orchidaceae. Anggrek tersebut memiliki tipe pertumbuhan simpodial. Secara umum tanaman dewasa yang telah selesai berbunga akan menghasilkan tunas anakan (offshoot) dari bagian pangkal batang bawah. Perbanyakan secara konvensional melalui pemisahan anakan, tetapi perlu waktu yang cukup lama. Birk (1983) mengemukakan bahwa dalam perbanyakan Paphiopedilum sp. melalui pemisahan tunas anakan harus memperhatikan kondisi pertumbuhannya, yaitu telah memiliki akar yang cukup untuk mendukung pertumbuhannya. Kondisi tersebut dapat dicapai dalam waktu dua sampai tiga tahun setelah muncul mata tunas anakan.

Paphiopedilum glaucophyllum yang berasal dari pulau Jawa ini cukup diminati penggemar anggrek, namun proses perbanyakannya jarang dilakukan petani anggrek. Hampir seluruh Paphiopedilum glaucophyllum yang dipasarkan di Indonesia merupakan tanaman yang berasal dari hutan. Habitatnya yang sangat terbatas dan pertumbuhannya yang lambat menyebabkan anggrek tersebut mudah hilang dari habitat aslinya, jika perambahan untuk tujuan komersial tetap dilakukan. Cribb (1997) memperkirakan 25 dari 60 spesies Paphiopedilum yang terdapat di alam liar sangat terancam keberadaannya, dengan penyebab utamanya adalah perambahan untuk tujuan komersial. Perdagangan internasional terhadap spesies liar Paphiopedilum telah dibatasi dengan menempatkan seluruh spesiesnya dalam Appendix I dari CITES (Convention in Trade on Endangered Spesies of Flora and Fauna).

Metode perbanyakan tanaman secara in vitro melalui proliferasi tunas adventif merupakan cara untuk mendapatkan tanaman dalam jumlah besar dalam waktu singkat dan efisien. Perbanyakan melalui tunas aksilar memiliki peluang yang lebih rendah untuk dapat menghasilkan tunas dalam jumlah besar. Metode tersebut dapat dijadikan jalan keluar yang tepat untuk mengatasi masalah perbanyakan Paphiopedilum glaucophyllum. Pengecambahan biji melalui metode in vitro digunakan dalam perbanyakan Paphiopedilum, terutama untuk menghasilkan hibrida. Cara lain dalam perbanyakan in vitro Paphiopedilum adalah menggunakan jaringan tanaman sebagai sumber eksplan. Ting-Yu et al. (2002) menggunakan ruas batang dari planlet Paphiopedilum philippinense (hibrida PH59 dan PH60) sebagai eksplan yang diregenerasi secara in vitro menjadi tanaman lengkap pada media MS (Murashige dan Skoog) setengah konsentrasi hara makro dan mikro yang ditambah TDZ dan 2,4D.

Sitokinin dan auksin adalah zat pengatur tumbuh (ZPT) yang sangat diperlukan untuk mengarahkan pertumbuhan pada media kultur in vitro (Chawla, 2002). BAP (dikombinasikan dengan 2,4-D) dan dua jenis media (MS dan KC) digunakan sebagai perlakuan untuk menghasilkan proliferasi tunas adventif dari planlet Paphiopedilum glaucophyllum. Tujuan Penelitian ini adalah untuk mempelajari pengaruh jenis media dan BAP terhadap daya proliferasi tunas adventif dari planlet Paphiopedilum glaucophyllum secara in vitro dan mendapatkan komposisi media yang optimal untuk perbanyakan Paphiopedilum glaucophyllum melalui induksi proliferasi tunas adventif secara in vitro.

\section{BAHAN DAN METODE}

Penelitian dilaksanakan di Laboratorium Bioteknologi Tanaman, Departemen Agronomi dan Hortikultura, Fakultas Pertanian, Institut Pertanian Bogor, mulai bulan Juni sampai Oktober 2009. Bahan tanaman yang digunakan adalah planlet Paphiopedilum glaucophyllum berumur 1 tahun 9 bulan yang diperoleh dari Pusat Konservasi Tumbuhan (PKT) Kebun Raya Bogor. Zat pengatur tumbuh yang digunakan adalah BAP dan 2,4-D, dengan media dasar dari komposisi MS (Murashige dan Skoog) dan KC (Knudson C). Bahan yang lain adalah aquades sebagai pelarut media dasar MS dan KC, agar sebagai pemadat media, dan alkohol $70 \%$ sebagai sterilan alat tanam. Alat-alat yang dipakai adalah botol kultur dengan volume $300 \mathrm{ml}$, autoklaf, magnetik stirrer, gelas ukur, labu erlenmeyer, laminar air flow cabinet (LAFC), pisau scalpel, petridish, lampu bunsen, dan pinset.

Percobaan menggunakan Rancangan Acak Lengkap dan rancangan perlakuan yang disusun secara Faktorial dengan dua faktor perlakuan. Faktor pertama adalah media, yaitu dua jenis media dasar (media MS dan KC) yang terdiri atas empat taraf konsentrasi hara makro dan mikro, yaitu 1/4 konsentrasi, 1/2 konsentrasi, 3/4 konsentrasi, dan 1 konsentrasi. Faktor kedua adalah BAP yang terdiri atas dua 
taraf konsentrasi, yaitu $1 \mathrm{mg} \mathrm{L}^{-1}$ dan $2 \mathrm{mg} \mathrm{L}^{-1}$. Zat pengatur tumbuh lain yang diberikan ke dalam setiap media adalah $0.5 \mathrm{mg} \mathrm{L}^{-1}$ 2.4-D. Pada penelitian ini terdapat enam belas kombinasi perlakuan yang disajikan pada Tabel 1.

Tabel 1. Kombinasi perlakuan media (MS dan KC) dan BAP

\begin{tabular}{|c|c|c|c|}
\hline No. & $\begin{array}{l}\text { Jenis } \\
\text { Media }\end{array}$ & $\begin{array}{c}\text { Konsentrasi } \\
\text { Hara Makro } \\
\text { dan Mikro }\end{array}$ & $\begin{array}{l}\text { Zat Pengatur } \\
\text { Tumbuh }\end{array}$ \\
\hline 1 & MS 1 & $\begin{array}{c}\text { MS 1/4 } \\
\text { Konsentrasi }\end{array}$ & $\begin{array}{c}1 \mathrm{mg} \mathrm{L}^{-1} \mathrm{BAP}+ \\
0.5 \mathrm{mg} \mathrm{L}^{-1} 2,4 \mathrm{D}\end{array}$ \\
\hline 2 & MS 2 & $\begin{array}{c}\text { MS 1/2 } \\
\text { Konsentrasi }\end{array}$ & $\begin{array}{c}1 \mathrm{mg} \mathrm{L}^{-1} \mathrm{BAP}+ \\
0.5 \mathrm{mg} \mathrm{L}^{-1} \quad 2,4 \mathrm{D}\end{array}$ \\
\hline 3 & MS 3 & $\begin{array}{c}\text { MS 3/4 } \\
\text { Konsentrasi }\end{array}$ & $\begin{array}{c}1 \mathrm{mg} \mathrm{L}^{-1} \mathrm{BAP}+ \\
0.5 \mathrm{mg} \mathrm{L}^{-1} 2,4 \mathrm{D}\end{array}$ \\
\hline 4 & MS 4 & $\begin{array}{c}\text { MS } 1 \\
\text { Konsentrasi }\end{array}$ & $\begin{array}{c}1 \mathrm{mg} \mathrm{L}^{-1} \mathrm{BAP}+ \\
0.5 \mathrm{mg} \mathrm{L}^{-1} 2,4 \mathrm{D}\end{array}$ \\
\hline 5 & MS 5 & $\begin{array}{c}\text { MS 1/4 } \\
\text { Konsentrasi }\end{array}$ & $\begin{array}{c}2 \mathrm{mg} \mathrm{L}^{-1} \mathrm{BAP}+ \\
0.5 \mathrm{mg} \mathrm{L}^{-1} 2,4 \mathrm{D}\end{array}$ \\
\hline 6 & MS 6 & $\begin{array}{c}\text { MS } 1 / 2 \\
\text { Konsentrasi }\end{array}$ & $\begin{array}{l}2 \mathrm{mg} \mathrm{L}^{-1} \mathrm{BAP}+ \\
0.5 \mathrm{mg} \mathrm{L}^{-1} 2,4 \mathrm{D}\end{array}$ \\
\hline 7 & MS 7 & $\begin{array}{c}\text { MS 3/4 } \\
\text { Konsentrasi }\end{array}$ & $\begin{array}{l}2 \mathrm{mg} \mathrm{L}^{-1} \mathrm{BAP}+ \\
0.5 \mathrm{mg} \mathrm{L}^{-1} 2,4 \mathrm{D}\end{array}$ \\
\hline 8 & MS 8 & $\begin{array}{c}\text { MS } 1 \\
\text { Konsentrasi }\end{array}$ & $\begin{array}{c}2 \mathrm{mg} \mathrm{L}^{-1} \mathrm{BAP}+ \\
0.5 \mathrm{mg} \mathrm{L}^{-1} 2,4 \mathrm{D}\end{array}$ \\
\hline 9 & $\mathrm{KC} 1$ & $\begin{array}{c}\text { KC } 1 / 4 \\
\text { Konsentrasi }\end{array}$ & $\begin{array}{c}1 \mathrm{mg} \mathrm{L}^{-1} \mathrm{BAP}+0.5 \\
\mathrm{mg} \mathrm{L}^{-1} \quad 2,4 \mathrm{D}\end{array}$ \\
\hline 10 & $\mathrm{KC} 2$ & $\begin{array}{c}\text { KC } 1 / 2 \\
\text { Konsentrasi }\end{array}$ & $\begin{array}{l}1 \mathrm{mg} \mathrm{L}^{-1} \mathrm{BAP}+ \\
0.5 \mathrm{mg} \mathrm{L}^{-1} 2,4 \mathrm{D}\end{array}$ \\
\hline 11 & KC 3 & $\begin{array}{c}\text { KC } 3 / 4 \\
\text { Konsentrasi }\end{array}$ & $\begin{array}{c}1 \mathrm{mg} \mathrm{L}^{-1} \mathrm{BAP}+ \\
0.5 \mathrm{mg} \mathrm{L}^{-1} 2,4 \mathrm{D}\end{array}$ \\
\hline 12 & $\mathrm{KC} 4$ & $\begin{array}{c}\text { KC } 1 \\
\text { Konsentrasi }\end{array}$ & $\begin{array}{c}1 \mathrm{mg} \mathrm{L}^{-1} \mathrm{BAP}+ \\
0.5 \mathrm{mg} \mathrm{L}^{-1} 2,4 \mathrm{D}\end{array}$ \\
\hline 13 & KC 5 & $\begin{array}{c}\mathrm{KC} 1 / 4 \\
\text { Konsentrasi }\end{array}$ & $\begin{array}{c}2 \mathrm{mg} \mathrm{L}^{-1} \mathrm{BAP}+ \\
0.5 \mathrm{mg} \mathrm{L}^{-1} 2,4 \mathrm{D}\end{array}$ \\
\hline 14 & KC 6 & $\begin{array}{c}\text { KC } 1 / 2 \\
\text { Konsentrasi }\end{array}$ & $\begin{array}{c}2 \mathrm{mg} \mathrm{L}^{-1} \mathrm{BAP}+ \\
0.5 \mathrm{mg} \mathrm{L}^{-1} 2,4 \mathrm{D}\end{array}$ \\
\hline 15 & KC 7 & $\begin{array}{c}\mathrm{KC} \mathrm{3/4} \\
\text { Konsentrasi }\end{array}$ & $\begin{array}{c}2 \mathrm{mg} \mathrm{L}^{-1} \mathrm{BAP}+ \\
0.5 \mathrm{mg} \mathrm{L}^{-1} 2,4 \mathrm{D}\end{array}$ \\
\hline 16 & $\mathrm{KC} 8$ & $\begin{array}{c}\text { KC } 1 \\
\text { Konsentrasi }\end{array}$ & $\begin{array}{c}2 \mathrm{mg} \mathrm{L}^{-1} \mathrm{BAP}+ \\
0.5 \mathrm{mg} \mathrm{L}^{-1} 2,4 \mathrm{D}\end{array}$ \\
\hline
\end{tabular}

\section{HASIL DAN PEMBAHASAN}

Planlet Paphiopedilum glaucophyllum memiliki akar yang setiap permukaannya ditutupi oleh rambut halus, hal tersebut menimbulkan kesulitan sterilisasi jika terjadi kontaminasi pada planlet. Daya tahan planlet terhadap sterilan seperti Sodium hypoclorit sangat rendah, planlet yang disterilisasi dengan Sodium hypoclorit $5 \%$ selama 5 menit akan menjadi coklat setelah beberapa hari ditanam dan akhirnya mati. Subkultur pada media baru dilakukan pada saat terjadi kontaminasi hanya pada media saja, sedangkan planlet masih dalam kondisi steril. Hal tersebut dapat mengurangi jumlah planlet mati akibat kontaminasi. Jumlah planlet mati adalah $36(25 \%)$ dari 144 jumlah planlet keseluruhan.

Perlakuan media (MS dan KC) dan sitokinin jenis BAP tidak menunjukkan pengaruhnya terhadap proliferasi tunas adventif dari planlet Paphiopedilum glaucophyllum sampai 16 minggu setelah tanam (MST). Semua planlet dari setiap kombinasi perlakuan tidak menghasilkan tunas baru. Jumlah tunas tetap pada seluruh planlet, yaitu satu tunas per planlet. Menurut Wiendi et al. (1992), secara in vitro pembentukan tunas melalui morfogenesis langsung ataupun tidak langsung sangat tergantung pada jenis dan konsentrasi yang tepat dari senyawa organik, inorganik, dan zat pengatur tumbuh (ZPT).

Chen dan Piluek (1995) melaporkan bahwa TDZ lebih efektif dalam mendorong pembentukan tunas pada Phalaenopsis hibrida dibandingkan BAP selama 8 MST. Pengaruh yang sama dari TDZ dilaporkan oleh Jen Tsung dan Wei Chin (2000), dimana $1 \mathrm{mg} \mathrm{L}^{-1} \mathrm{TDZ}$ mampu menginduksi tunas dari eksplan kalus yang berasal dari tangkai bunga Oncidium Sweet Sugar selama 8 MST. Le et al. (1999) menemukan pengaruh TDZ dalam mendorong pembentukan tunas eksplan potongan melintang batang (transverse thin cell layer) dari Rhynchostylis gigantea meningkat dengan mengkombinasikannya dengan BAP selama 4 MST.

Pengaruh perlakuan terhadap variabel pengamatan jumlah total helai daun dari planlet Paphiopedilum glaucophyllum secara nyata ditunjukkan dari perlakuan media secara tunggal saat umur planlet 9 MST sampai akhir pengamatan (16 MST) (Tabel 2). BAP dan interaksinya dengan media tidak menunjukkan pengaruh yang nyata terhadap jumlah total helai daun.

Perlakuan media berpengaruh nyata terhadap pertumbuhan daun dari planlet Paphiopedilum glaucophyllum. Media KC pada $3 / 4$ konsentrasi hara makro dan mikro menunjukkan jumlah total helai daun tertinggi, yaitu 6.3 helai daun per planlet (Tabel 2). Jumlah total helai daun per planlet terendah adalah dari media MS pada 1 konsentrasi hara makro dan mikro dan $\mathrm{KC}$ pada $1 / 4$ konsentrasi hara makro dan mikro, yaitu 4.9 helai daun per planlet. 
Tabel 2. Pengaruh konsentrasi hara makro dan mikro media (MS dan KC) terhadap jumlah total helai daun Paphiopedilum glaucophyllum J.J. Smith secara in vitro

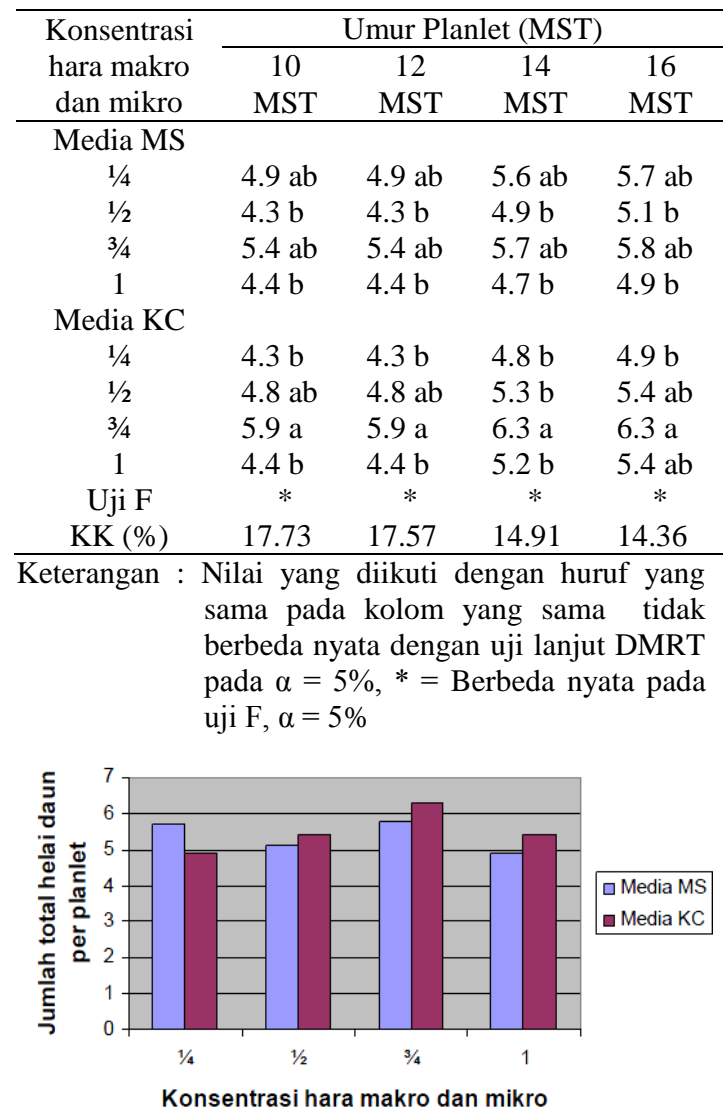

Gambar 1. Pengaruh konsentrasi media (MS dan KC) terhadap pertumbuhan daun planlet $P$. glaucophyllum J.J. Smith secara in vitro pada 16 MST

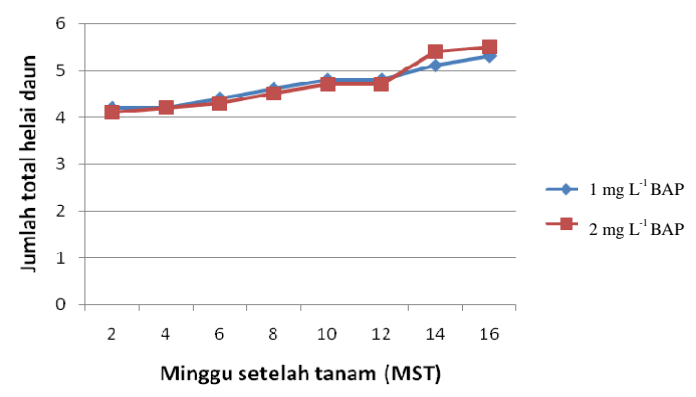

Gambar 2. Pengaruh dua taraf BAP terhadap pertumbuhan daun planlet $P$. glaucophyllum J.J. Smith secara in vitro
Konsentrasi hara makro dan mikro pada kedua jenis media berpengaruh terhadap pertumbuhan daun planlet yang dapat dilihat dari jumlah total helai daun yang dihasilkan dari masing-masing konsentrasi media. Pertumbuhan daun optimum diperoleh pada $3 / 4$ konsentrasi hara makro dan mikro (Gambar 1). BAP pada konsentrasi 1 dan $2 \mathrm{mg} \mathrm{L}^{-1}$ tidak memperlihatkan perbedaan yang nyata terhadap pertumbuhan daun planlet Paphiopedilum glaucophyllum. Jumlah total helai daun yang dihasilkan terlihat tidak berbeda pada dua konsentrasi BAP yang digunakan (Gambar 2).

Jumlah total helai daun tertinggi pada 16 MST ditunjukkan oleh planlet pada media $\mathrm{KC} 3 / 4$ konsentrasi hara makro dan mikro yang diberi $2 \mathrm{mg} \mathrm{L}^{-1}$ BAP (KC 6) (Tabel 3). Wiendi et al. (1992) melaporkan bahwa morfogenesis daun dan akar dipengaruhi oleh perbandingan (nisbah) zat pengatur tumbuh (ZPT) auksin dan sitokinin. Perbandingan auksin dan sitokinin yang tinggi akan mendorong morfogenesis akar, sedangkan perbandingan sitokinin dan auksin yang tinggi akan mendorong pembentukan tunas. Walaupun demikian, secara umum morfogenesis sangat tergantung pada jenis dan konsentrasi yang tepat dari senyawa organik, anorganik, dan zat pengatur tumbuh.

Pengaruh perlakuan terhadap jumlah total akar planlet Paphiopedilum glaucophyllum secara nyata ditunjukkan dari perlakuan media secara tunggal saat umur planlet 6 sampai 12 MST (Tabel 4). BAP dan interaksinya dengan media (MS dan KC) tidak berbeda nyata sampai 16 MST. Diantara dua jenis media (MS dan KC) pada empat taraf konsentrasi hara makro dan mikro, media KC $3 / 4$ konsentrasi hara makro dan mikro menghasilkan jumlah total akar tertinggi sampai 16 MST, yaitu 5.5 akar per planlet. Jumlah total akar terendah diperlihatkan oleh planlet pada media MS 1/2 konsentrasi hara makro dan mikro dan KC 1/4 konsentrasi hara makro dan mikro, masing-masing adalah 4.1 akar per planlet. Media KC diduga memiliki pengaruh yang baik untuk pertumbuhan akar pada $3 / 4$ konsentrasi hara makro dan mikro. 
Tabel 3. Pengaruh perlakuan terhadap jumlah total helai daun planlet $P$. glaucophyllum J.J. Smith secara in vitro

\begin{tabular}{|c|c|c|c|c|c|c|c|c|}
\hline \multirow{3}{*}{ Perlakuan } & \multicolumn{8}{|c|}{ Jumlah Total Helai Daun } \\
\hline & \multicolumn{8}{|c|}{ Minggu Setelah Tanam (MST) } \\
\hline & 2 & 4 & 6 & 8 & 10 & 12 & 14 & 16 \\
\hline MS 1 & 4.1 & 4.1 & 4.1 & 4.1 & 4.2 & 4.2 & 5.0 & 5.0 \\
\hline MS 2 & 4.5 & 4.5 & 4.7 & 4.7 & 4.8 & 4.8 & 5.1 & 5.3 \\
\hline MS 3 & 4.2 & 4.2 & 4.8 & 5.1 & 5.2 & 5.2 & 5.3 & 5.4 \\
\hline MS 4 & 3.9 & 3.9 & 3.9 & 4.0 & 4.4 & 4.4 & 4.5 & 4.9 \\
\hline MS 5 & 4.9 & 4.9 & 5.0 & 5.3 & 5.5 & 5.5 & 6.2 & 6.4 \\
\hline MS 6 & 3.8 & 3.8 & 3.8 & 3.8 & 3.8 & 3.8 & 4.7 & 4.8 \\
\hline MS 7 & 5.0 & 5.0 & 5.2 & 5.4 & 5.5 & 5.5 & 6.1 & 6.2 \\
\hline MS 8 & 3.8 & 3.8 & 4.2 & 4.3 & 4.3 & 4.4 & 4.9 & 4.9 \\
\hline KC 1 & 4.4 & 4.4 & 4.5 & 4.9 & 5.0 & 5.0 & 5.2 & 5.3 \\
\hline KC 2 & 4.2 & 4.2 & 4.4 & 4.8 & 5.0 & 5.0 & 5.3 & 5.4 \\
\hline KC 3 & 4.3 & 4.2 & 4.7 & 5.1 & 5.7 & 5.7 & 6.1 & 6.1 \\
\hline $\mathrm{KC} 4$ & 3.9 & 3.9 & 4.1 & 4.3 & 4.5 & 4.5 & 4.9 & 5.1 \\
\hline KC 5 & 3.3 & 3.3 & 3.3 & 3.5 & 3.7 & 3.7 & 4.4 & 4.5 \\
\hline KC 6 & 4.0 & 4.0 & 4.4 & 4.5 & 4.7 & 4.7 & 5.3 & 5.4 \\
\hline KC 7 & 5.4 & 5.4 & 5.8 & 5.8 & 6.1 & 6.1 & 6.4 & 6.4 \\
\hline KC 8 & 3.2 & 3.2 & 3.2 & 3.8 & 4.2 & 4.2 & 5.4 & 5.8 \\
\hline $\mathrm{Uji} F$ & tn & tn & tn & tn & tn & tn & tn & tn \\
\hline KK (\%) & 20.55 & 20.47 & 20.62 & 19.23 & 17.73 & 17.57 & 14.91 & 14.36 \\
\hline
\end{tabular}

Keterangan: $\mathrm{tn}=$ tidak berbeda nyata pada uji $\mathrm{F}$ dengan $\alpha=5 \%$

Tabel 4. Pengaruh konsentrasi hara makro dan mikro media (MS dan KC) terhadap jumlah total akar planlet $P$. glaucophyllum J.J. Smith secara in vitro

\begin{tabular}{cllll}
\hline \multirow{2}{*}{ Konsentrasi hara makro dan mikro } & \multicolumn{4}{c}{ Umum Planlet (MST) } \\
\cline { 2 - 5 } & $6 \mathrm{MST}$ & $8 \mathrm{MST}$ & $10 \mathrm{MST}$ & $12 \mathrm{MST}$ \\
\hline Media MS & & & & \\
$1 / 4$ & $3.4 \mathrm{~b}$ & $3.8 \mathrm{~b}$ & $4.1 \mathrm{~b}$ & $4.1 \mathrm{~b}$ \\
$1 / 2$ & $3.4 \mathrm{~b}$ & $3.8 \mathrm{~b}$ & $3.8 \mathrm{~b}$ & $3.9 \mathrm{~b}$ \\
$3 / 4$ & $4.2 \mathrm{ab}$ & $4.7 \mathrm{ab}$ & $4.8 \mathrm{ab}$ & $4.8 \mathrm{ab}$ \\
1 & $3.7 \mathrm{~b}$ & $3.9 \mathrm{~b}$ & $3.9 \mathrm{~b}$ & $3.9 \mathrm{~b}$ \\
Media KC & & & & \\
$1 / 4$ & $3.2 \mathrm{~b}$ & $3.8 \mathrm{~b}$ & $3.9 \mathrm{~b}$ & $3.9 \mathrm{~b}$ \\
$1 / 2$ & $3.9 \mathrm{ab}$ & $4.7 \mathrm{ab}$ & $4.7 \mathrm{ab}$ & $4.8 \mathrm{ab}$ \\
$3 / 4$ & $4.8 \mathrm{a}$ & $5.3 \mathrm{a}$ & $5.4 \mathrm{a}$ & $5.4 \mathrm{a}$ \\
1 & $4.1 \mathrm{ab}$ & $4.3 \mathrm{ab}$ & $4.5 \mathrm{ab}$ & $4.5 \mathrm{ab}$ \\
Uji F & $*$ & $*$ & $*$ & $*$ \\
KK $(\%)$ & 20.39 & 18.62 & 18.85 & 19.33 \\
\hline
\end{tabular}

Keterangan : Nilai yang diikuti dengan huruf yang sama pada kolom yang sama tidak berbeda nyata dengan uji lanjut DMRT pada $\alpha=5 \%, *=$ Berbeda nyata pada uji F, $\alpha=5 \%$

Pertumbuhan akar terhambat pada media dengan konsentrasi hara makro dan mikro yang lebih rendah dari $3 / 4$ konsentrasi hara makro dan mikro (Gambar 3). Penggunaan BAP pada konsentrasi 1 dan $2 \mathrm{mg} \mathrm{L}^{-1}$ tidak memperlihatkan perbedaan yang nyata terhadap pertumbuhan akar (Gambar 4). Jumlah total akar yang dihasilkan pada dua taraf BAP tersebut tidak berbeda secara signifikan 


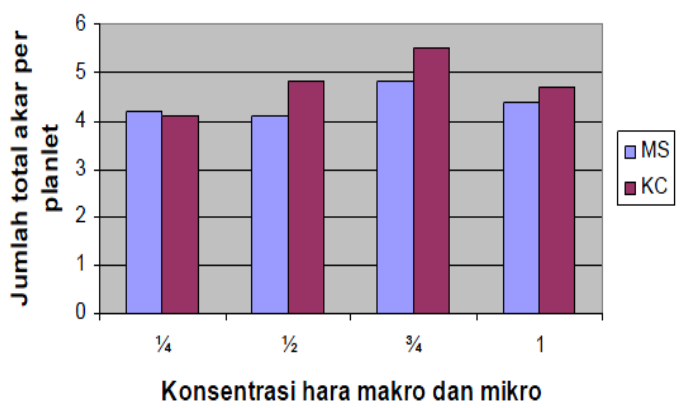

Gambar 3. Pengaruh konsentrasi media (MS dan KC) terhadap pertumbuhan akar planlet $P$. glaucophyllum J.J. Smith secara in vitro pada $16 \mathrm{MST}$

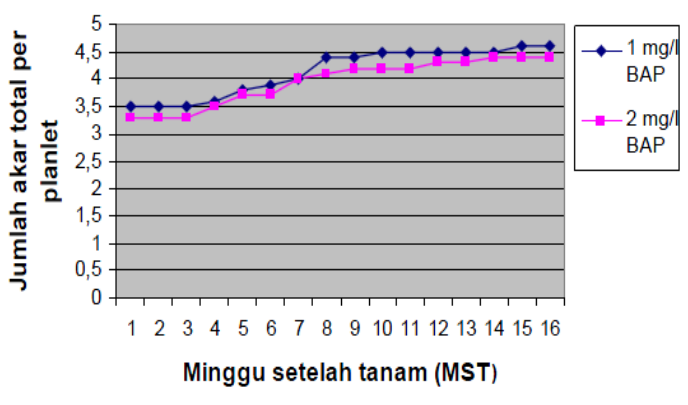

Gambar 4. Pengaruh dua taraf BAP terhadap pertumbuhan akar planlet $P$. glaucophyllum J.J. Smith secara in vitro

Pengaruh interaksi antara media (MS dan KC) dan BAP tidak berbeda nyata terhadap pertumbuhan akar. Pertumbuhan akar pada media KC 3/4 konsentrasi hara makro dan mikro yang ditambahkan $1 \mathrm{mg} \mathrm{L}^{-1} \mathrm{BAP}(\mathrm{KC} 2)$ relatif lebih cepat diantara perlakuan yang lain. Hal tersebut dapat dilihat dari jumlah total akar yang dihasilkan lebih tinggi pada 16 MST, yaitu 5.6 akar per planlet (Tabel 5).

Tabel 5. Pengaruh perlakuan terhadap jumlah akar total planlet Paphiopedilum glaucophyllum J.J. Smith secara in vitro

\begin{tabular}{|c|c|c|c|c|c|c|c|c|}
\hline \multirow{3}{*}{ Perlakuan } & \multicolumn{8}{|c|}{ Jumlah Total Akar } \\
\hline & \multicolumn{8}{|c|}{ Minggu Setelah Tanam (MST) } \\
\hline & 2 & 4 & 6 & 8 & 10 & 12 & 14 & 16 \\
\hline MS 1 & 2.6 & 2.7 & 3.0 & 3.5 & 3.8 & 4.0 & 4.0 & 4.1 \\
\hline MS 2 & 3.2 & 3.3 & 3.7 & 4.2 & 4.2 & 4.3 & 4.3 & 4.3 \\
\hline MS 3 & 3.6 & 3.8 & 4.1 & 4.4 & 4.5 & 4.5 & 4.5 & 4.5 \\
\hline MS 4 & 3.3 & 3.7 & 3.8 & 4.1 & 4.1 & 4.1 & 4.2 & 4.3 \\
\hline MS 5 & 3.6 & 3.7 & 3.8 & 4.1 & 4.2 & 4.2 & 4.2 & 4.2 \\
\hline MS 6 & 3.1 & 3.1 & 3.1 & 3.4 & 3.4 & 3.4 & 3.8 & 3.8 \\
\hline MS 7 & 3.7 & 4.0 & 4.2 & 4.8 & 5.0 & 5.0 & 5.1 & 5.1 \\
\hline MS 8 & 3.1 & 3.3 & 3.5 & 3.6 & 3.8 & 3.8 & 4.3 & 4.4 \\
\hline $\mathrm{KC} 1$ & 3.2 & 3.2 & 3.4 & 4.1 & 4.1 & 4.1 & 4.2 & 4.4 \\
\hline KC 2 & 4.2 & 4.2 & 4.2 & 5.2 & 5.2 & 5.2 & 5.3 & 5.3 \\
\hline KC 3 & 3.7 & 3.8 & 4.6 & 5.3 & 5.5 & 5.5 & 5.6 & 5.6 \\
\hline KC 4 & 3.8 & 4.0 & 4.1 & 4.3 & 4.4 & 4.4 & 4.4 & 4.4 \\
\hline KC 5 & 2.7 & 2.8 & 3.0 & 3.5 & 3.6 & 3.6 & 3.6 & 3.6 \\
\hline KC 6 & 3.1 & 3.5 & 3.6 & 4.1 & 4.1 & 4.3 & 4.3 & 4.3 \\
\hline KC 7 & 4.3 & 4.4 & 4.8 & 5.2 & 5.2 & 5.3 & 5.3 & 5.3 \\
\hline $\mathrm{KC} 8$ & 3.0 & 3.2 & 4.0 & 4.3 & 4.5 & 4.5 & 4.8 & 4.8 \\
\hline Uji F & $\operatorname{tn}$ & tn & $\operatorname{tn}$ & $\operatorname{tn}$ & $\operatorname{tn}$ & tn & $\operatorname{tn}$ & $\operatorname{tn}$ \\
\hline KK (\%) & 25.05 & 23.66 & 20.39 & 18.62 & 18.85 & 19.33 & 19.67 & 19.21 \\
\hline
\end{tabular}

Keterangan: $\mathrm{tn}=$ Tidak berbeda nyata pada uji $\mathrm{F}$ dengan $\alpha=5 \%$. 
Pembentukan kalus diawali dengan pembesaran bagian ujung akar yang mulai terlihat pada 6 MST. Kalus mulai terlihat pada 9 MST. Perlakuan BAP (1 dan $2 \mathrm{mg} \mathrm{L}^{-1}$ ) menunjukkan pengaruh yang nyata terhadap pembentukan kalus dari planlet Paphiopedilum glaucophyllum. Perlakuan media dan interaksi antara media dan BAP tidak menunjukkan perbedaan yang nyata terhadap pembentukan kalus. Sebanyak $38.24 \%$ planlet menghasilkan kalus dari seluruh planlet Paphiopedilum glaucophyllum dalam percobaan.

Media MS dan KC pada empat taraf konsentrasi $(1,3 / 4,1 / 2,1 / 4$ konsentrasi hara makro dan mikro) tidak berbeda nyata terhadap jumlah planlet berkalus Paphiopedilum glaucophyllum. Kurniati et al. (2012) melaporkan penggunaan media MS tanpa TDZ pada potongan petal yang di kulturkan secara in vitro tidak dapat menginduksi terbentuknya kalus. Diantara dua jenis media tersebut, media MS pada $3 / 4$ konsentrasi hara makro dan mikro dan media KC pada $1 / 2$ konsentrasi hara makro dan mikro menghasilkan jumlah planlet berkalus yang lebih tinggi diantara konsentrasi hara makro dan mikro yang lain pada kedua jenis media, yaitu $55.56 \%$ planlet berkalus (Tabel 6). Pada media MS, pembentukan kalus optimum diperoleh pada 3/4 konsentrasi hara makro dan mikro, pada konsentrasi hara makro dan mikro yang lebih tinggi dan lebih rendah dari konsentrasi tersebut menyebabkan pembentukan kalus terhambat. Pada media KC, pembentukan kalus optimum diperoleh pada $1 \frac{1}{2}$ konsentrasi hara makro dan mikro.

Pembentukan kalus terjadi akibat jaringan dari bagian ujung akar planlet Paphiopedilum glaucophyllum mengalami dediferensiasi, yang secara nyata dipengaruhi oleh BAP. Jumlah planlet berkalus tertinggi diperoleh pada perlakuan 1 $\mathrm{mg} \mathrm{L}^{-1}$ BAP, yaitu $48.61 \%$ (Tabel 7). Menurut Chawla (2002), fenomena dimana sel dewasa kembali pada keadaan meristematik dan membentuk jaringan kalus yang belum terdiferensiasi disebut sebagai dediferensiasi. Menurut Wiendi et al. (1992), kemampuan suatu jaringan dalam membentuk kalus dan laju pertumbuhan kalus tergantung pada media, zat pengatur tumbuh (ZPT) yang digunakan dan faktor lingkungan lainnya. Roy dan Banerjee (2003) melaporkan pengaruh yang tinggi dari penggunaan $1 \mathrm{mg}$ $\mathrm{L}^{-1}$ BAP yang dikombinasikan dengan $0.5 \mathrm{mg}$ $\mathrm{L}^{-1}$ NAA terhadap frekuensi pembentukan kalus eksplan pucuk Dendrobium fimbriatum var. oculatum pada modifikasi media KC selama 8 MST. Kurniati et al. (2012) melaporkan penggunaan media MS tanpa TDZ pada potongan petal yang dikulturkan secara in vitro tidak dapat menginduksi terbentuknya kalus.

Tabel 6. Pengaruh konsentrasi media terhadap jumlah planlet berkalus $P$. glaucophyllum J.J. Smith secara in vitro pada $16 \mathrm{MST}$

\begin{tabular}{cc}
\hline $\begin{array}{c}\text { Konsentrasi hara makro } \\
\text { dan mikro }\end{array}$ & $\begin{array}{c}\text { Jumlah planlet berkalus } \\
(\%)\end{array}$ \\
\hline Media MS & \\
$1 / 4$ & 22.22 \\
$1 / 2$ & 44.45 \\
$3 / 4$ & 55.56 \\
1 & 27.78 \\
Media KC & 33.33 \\
$1 / 4$ & 55.56 \\
$1 / 2$ & 22.22 \\
$3 / 4$ & 44.45 \\
1 & tn \\
Uji F & 68.4 \\
KK $(\%)$ & \\
\hline Keterangan $:$ tn $=$ Tidak berbeda nyata pada uji $\mathrm{F}$ \\
dengan a $=5 \%$ KK merupakan data \\
hasil transformasi dengan rumus \\
$\sqrt{\mathrm{x}+0.5}$
\end{tabular}

Tabel 7. Pengaruh dua taraf BAP terhadap jumlah planlet berkalus $P$. glaucophyllum J.J. Smith secara in vitro pada 16 MST

\begin{tabular}{cc}
\hline Konsentrasi BAP & $\begin{array}{c}\text { Jumlah planlet } \\
\text { berkalus }(\%)\end{array}$ \\
\hline $1 \mathrm{mg} \mathrm{L}^{-1}$ & 48.61 \\
$2 \mathrm{mg} \mathrm{L}^{-1}$ & 27.78 \\
$\mathrm{Uji} \mathrm{F}$ & $*$ \\
$\mathrm{KK}(\%)$ & 68.4 \\
\hline Keterangan $:$ tn $=$ Tidak berbeda nyata pada uji $\mathrm{F}$ \\
dengan a = 5\%; KK merupakan data \\
hasil transformasi dengan rumus \\
$\sqrt{\mathrm{x}+0.5}$
\end{tabular}

Interaksi antara perlakuan media (MS dan KC) dan BAP tidak menunjukkan perbedaan yang nyata terhadap pembentukan kalus dari planlet Paphiopedilum glaucophyllum. Pembentukan kalus terhambat pada media yang ditambahkan $2 \mathrm{mg} \mathrm{L}^{-1}$ BAP. Peningkatan jumlah planlet berkalus dari media yang ditambahkan $1 \mathrm{mg} \mathrm{L}^{-1}$ BAP ke media yang ditambahkan $2 \mathrm{mg} \mathrm{L}^{-1}$ BAP hanya terjadi pada media KC $1 / 2$ konsentrasi hara makro dan mikro (Gambar 5). Media MS 1/2 
konsentrasi hara makro dan mikro menghasilkan jumlah planlet berkalus yang sama pada dua taraf konsentrasi BAP, yaitu sebanyak $22.22 \%$.

Kalus yang terbentuk memiliki struktur padat (masif). Kalus tersebut memiliki warna yang beragam, akan tetapi sebagian besar kalus berwarna putih kekuningan. Menurut Evans (2003), variasi kalus bergantung pada jaringan eksplan yang digunakan, umur kalus dan kondisi lingkungan tumbuhnya. Kalus dapat berwarna putih, hijau, ataupun berwarna gelap karena adanya pigmen antosianin. Kalus terdiri atas massa sel yang tersusun renggang dan bersifat friable (mudah dipisahkan), atau berlignin dengan susunan massa sel yang rapat dan bertekstur keras (non-friable).

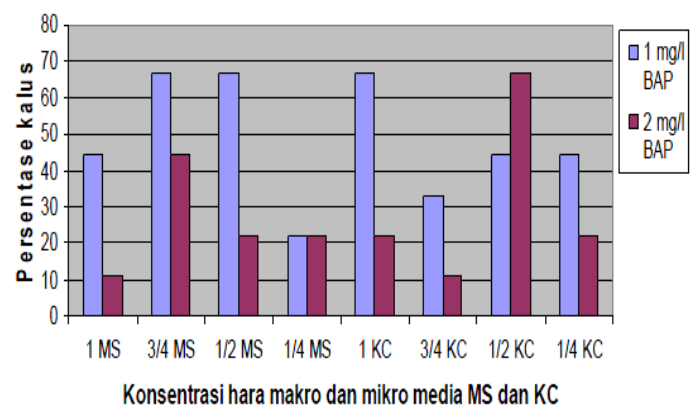

Gambar 5. Respon jumlah planlet berkalus $P$. glaucophyllum karena kombinasi perlakuan media (MS dan KC) dan BAP pada 16 MST

Pencoklatan (browning) terjadi pada kalus yang dihasilkan oleh planlet Paphiopedilum glaucophyllum. Dari jumlah keseluruhan planlet yang membentuk kalus, sekitar $40 \%$ kalus mengalami perubahan warna menjadi coklat kehitaman. Perubahan tersebut terjadi pada saat akar mulai membesar atau setelah akar mulai menjadi kalus. Menurut Hutami (2008), perubahan warna menjadi coklat (pencoklatan) dalam kultur jaringan terjadi karena akumulasi polifenol oksidase yang dilepas atau disintesis jaringan dalam kondisi teroksidasi ketika sel dilukai. Jaringan yang diisolasi menjadi berwarna coklat dan atau kehitaman serta gagal untuk tumbuh.

Protocorm Like Bodies (PLB) tidak dihasilkan oleh planlet Paphiopedilum glaucophyllum selama 16 MST pada semua kombinasi perlakuan yang digunakan dalam penelitian. Kalus yang dihasilkan oleh planlet Paphiopedilum glaucophyllum tidak mengalami perkembangan yang mengarah pada pembentukan Protocorm Like Bodies (PLB). Menurut Sheelavanthmath dan Murthy (2005), BA lebih efektif dalam menginduksi Protocorm Like Bodies (PLB) dari eksplan protocorm dan daun dibandingkan TDZ dan Kinetin pada Aerides crispum sema 8 MST.

\section{KESIMPULAN}

Perlakuan BAP dengan dua taraf konsentrasi $\left(1 \mathrm{mg} \mathrm{L}^{-1}\right.$ dan $\left.2 \mathrm{mg} \mathrm{L}^{-1}\right)$ dan media (MS dan KC) dengan empat taraf konsentrasi hara makro dan mikro $(1,3 / 4,1 / 2$, dan $1 / 4$ konsentrasi hara makro dan mikro) tidak menghasilkan proliferasi tunas adventif dari planlet Paphiopedilum glaucophyllum sampai 16 MST. Jumlah tunas dari seluruh planlet tidak bertambah pada semua kombinasi perlakuan yang digunakan. Perlakuan media (MS dan KC) berpengaruh nyata terhadap pertumbuhan daun dan akar planlet Paphiopedilum glaucophyllum. Pertumbuhan daun dan akar optimum diperoleh pada 3/4 konsentrasi hara makro dan mikro dari kedua jenis media (MS dan KC).

Jumlah total helai daun tertinggi diperoleh dari planlet pada media KC $3 / 4$ konsentrasi hara makro dan mikro yang ditambah $2 \mathrm{mg} \mathrm{L}^{-1}$ BAP (KC 6), sedangkan jumlah akar total pada $\mathrm{KC} 3 / 4$ konsentrasi hara makro dan mikro yang ditambah $1 \mathrm{mg} \mathrm{L}^{-1}$ BAP (KC 2). BAP berpengaruh nyata terhadap jumlah planlet berkalus. Penggunaan $1 \mathrm{mg} \mathrm{L}^{-1}$ BAP (dikombinasikan dengan $0.5 \mathrm{mg} \mathrm{L}^{-1} 2.4$ D) menghasilkan jumlah planlet berkalus tertinggi pada semua konsentrasi hara makro dan mikro dari media (MS dan KC), kecuali $\mathrm{KC} 1 / 2$ konsentrasi hara makro dan mikro.

\section{SARAN}

Perlu pengujian terhadap BAP pada taraf yang lebih tinggi, yang secara umum digunakan untuk proliferasi tunas adventif pada anggrek. Perlu dicoba zat pengatur tumbuh (ZPT) yang berbeda secara tunggal atau kombinasi pada berbagai konsentrasi yang berbeda, begitu juga dengan formulasi media. Perlu percobaan lanjutan mengenai media dan zat pengatur tumbuh (ZPT) yang diperlukan dalam menginduksi perkembangan 
lain dari kalus yang dihasilkan pada penelitian ini, agar bisa dihasilkan planlet.

\section{DAFTAR PUSTAKA}

Bennett, K.S. 1985. The Tropical Asiatic Slipper Orchids. Angus \& Robertson Publishers. London.

Birk, L.A. 1983. The Paphiopedilum Grower's Manual. Pisang Press. Santa Barbara.

Chawla, H.S. 2002. Introduction to Plant Biotechnology. Science Publishers, Inc. New Hampshire.

Chen, Y., C. Piluek. 1995. Effects of thidiazuron and N6 benzyl aminopurine on shoot regeneration of Phalaenopsis. Plant Growth Regulation. 16: 99-101.

Cribb, P. 1997. Slipper Orchids of Borneo. Natural History Publications. Kinabalu.

Evans, D.E., J.O.D. Coleman, A. Kearns. 2003. Plant Cell Culture. BIOS Scientific Publishers. London and New York.

Hutami, S. 2008. Masalah pencoklatan pada kultur jaringan. J. AgroBiogen. 4(2): 83-88.

Jen-Tsung, C., C. Wei-Chin. 2000. Plant regeneration via embryo and shoot bud formation from flower-stalk explant of Oncidium Sweet Sugar. Plant Cell, Tissue Organ Cult. 62: 95-100.

Kurniati, R., A. Purwito, G.A. Wattimena, B. Marwito, Supenti. 2012. Induksi kalus tiga kulivar Lili dari petal bunga pada beberapa jenis media. J. Hort. Indonesia. 3(1): 17-23.

Le, B.V., N.T.H. Phuong, L.T.A. Hong, K.T.T. Van. 1999. High frequency shoot regeneration from Rhyncostylis gigantea (Orchidaceae) using thin cell layer. Plant Growth Regulation. 28: 179-185.

Mahendran, G., V.N. Bai. 2009. Mass propagation of Satyrium nepalense D. Don.-A medicinal orchid via seed culture. Sci. Hortic. 119: 203-207.

Roy, J., N. Banerjee. 2003. Induction of callus and plant regeneration from shoot-tip explants of Dendrobium fimbriatum Lindl. var. oculatum Hk. f. Sci. Hortic. 97: 333-340.

Sheelavanthmath, S.S, H.N. Murthy, B.P. Hema, E.J. Hahn, K.Y. Paek. 2005. High frequency of protocorm like bodies (PLBs) induction and plant regeneration from protocorm and leaf section of Aerides crispum. Sci. Hortic. 106: 395401.

Ting-Yu, C.C. Jen-Tsung, C. Wei-Chin. 2002. Multiple shoot formation and plant regeneration from stem nodal explants of Paphiopedilum orchids. In Vitro Cell. Dev. Biol.-Plant. 38: 595-597.

Wiendi, N., G.A. Wattimena, L.W. Gunawan. 1991. Perbanyakan tanaman. Hal.17-44. Dalam Tim Laboratorium Kultur Jaringan Tanaman (Eds.). Bioteknologi Tanaman. Pusat Antar Universitas Bioteknologi IPB. Bogor. 